\title{
PENGARUH KUALITAS PELAYANAN DAN KEPUASAN NASABAH TERHADAP LOYALITAS NASABAH PT. BANK INDEX LAMPUNG
}

\author{
Ria Octavia \\ Sekolah Tinggi Ilmu Ekonomi Al-MadaniBandar Lampung \\ Jl. Kavling Raya 14, Jl. Pramuka, Rajabasa, Kota Bandar Lampung, Lampung 35142 \\ E-mail: riaoctaviaa@gmail.com
}

\begin{abstract}
Abstrak: Tujuan dari penelitian ini adalah untuk mengetahui pengaruh kualitas pelayanan terhadap loyalitas nasabah, kualitas pelayanan terhadap kepuasan nasabah, kepuasan nasabah terhadap loyalitas. Dalam penelitian ini mengukur dampak kualitas pelayanan terhadap loyalitas secara langsung. Penelitian ini merupakan penelitian konfirmatori yaitu penelitian yang bertujuan untuk mengetahui apakah ada hubungan antara variabel yang telah dikembangkan dari penelitian sebelumnya dengan fakta atau kejadian aktual di lapangan. Populasi target dalam penelitian ini adalah pelanggan PT. Indeks Bank Kantor Cabang Lampung. Sampel diambil 150 orang dengan menggunakan teknik purposive sampling. Alat analisis yang digunakan untuk menguji hipotesis ini menggunakan analisis dalam Structural Equation Model. Hasil penelitian ini menunjukkan bahwa kualitas pelayanan berpengaruh terhadap kepuasan nasabah, kualitas pelayanan tidak berpengaruh langsung terhadap loyalitas nasabah, dan kepuasan nasabah berpengaruh terhadap loyalitas nasabah.
\end{abstract}

Kata kunci: Kepuasan nasabah; kualitas pelayanan; loyalitas nasabah.

\begin{abstract}
The purpose of this study was to determine the effect of service quality on customer loyalty, service quality on customer satisfaction, customer satisfaction to loyalty. In this study to measure the impact of service quality on loyalty directly. This study is a confirmatory study is research that aims to determine whether there is a relationship between variables that have been developed from previous studies with actual facts or events on the ground. The target population in this study are customers of PT. Bank Index Lampung Branch Office. Samples taken 150 people by using purposive sampling technique. Analyzer used to test this hypothesis using analysis in the Structural Equation Model. The results of this study indicate that service quality affect on customer satisfaction, service quality has no effect on customer loyalty directly, and customer satisfaction affect on customer loyalty.
\end{abstract}

Keywords: Customer satisfaction; service quality; loyalitas nasabah.

\section{PENDAHULUAN}

Meningkatnya tingkat persaingan antar bank saat ini membuat bank semakin berlomba-lomba untuk mendapatkan nasabah dengan cara meningkatkan pelayanan dan kinerja secara optimal. Peningkatan pelayanan dan kinerja tersebut tentunya diharapkan dapat meningkatkan kepuasan nasabah serta meningkatkan loyalitas dari nasabah sendiri.

Dalam industri perbankan, Sabir (2014) mengatakan bahwa persaingan bank yang kompetitif bisa meningkatkan keuntungan melalui penyediaan layanan yang superior kepada nasabah mereka. Elemen kunci dari kepuasan pelanggan adalah sifat hubungan antara pelanggan, penyedia produk dan layanan. Dengan demikian, baik produk dan kualitas layanan biasanya dicatat sebagai prasyarat penting untuk memuaskan pelanggan dan penahan dihargai. Mosahab et al. (2010) berpendapat bahwa kualitas pelayanan memainkan peran penting dalam kepuasan pelanggan di Bank Sepah dan manajer bank harus secara bertahap berusaha untuk melampaui harapan pelanggan.

Dimensi kualitas pelayanan yang dikembangkan Cronin et al.(1988) dibagi menjadi lima dimensi diantaranya tangibles; reliability;responsiveness; assurance; empathy.Cronin et al (1988) menyebutkan bahwa SERVQUAL dapat membantu Layanan dan Organisasi Pengecer dalam menilai harapan pelanggan dan persepsi Kualitas Layanan.Ini dapat fokus pada bidang inti di mana manajer perlu memperhatikan dan bertindak untuk meningkatkan Kualitas Layanan.

Menurut Akbar dan Parvez (2009) perusahaan saat ini harus menyadari perlunya belajar dan pemahaman berbagai kualitas pelayanan dari loyalitas pelanggan yang mungkin membantu mereka untuk mengembangkan basis pelanggan setia. Sebagaimana dinyatakan dalam literatur oleh Siddiqi (2011),Sabir et al. (2014) yang relevanpelayanan berkualitas tinggi membantu untuk menghasilkankepuasan pelanggan, loyalitas pelanggan,dan pertumbuhan pangsa pasar dengan memintapelanggan baru, dan meningkatkan produktivitasdan kinerja keuangan.

Mosahab et al. (2010) yang menemukan adanya hubungan positif antara kualitas pelayanan dan loyalitas pelanggan secara langsung. Jika proses kualitas pelayanan itu terjadi berulang-ulang, berkelanjutan dan dipupuk secara terus menerus maka akan memberikan kepuasan pada pelanggan sesuai harapan. 
Kepuasan pelanggan adalah salah satu jenis respon (kognitif atau emosional). Untuk itu diperlukan upaya yang lebih dimana perusahaan melihat lebih jauh ke depan, tidak hanya sekedar memberikan kepuasan kepada pelanggan tetapi juga menciptakan pelanggan menjadi loyal kepada perusahaan. Hal serupa didukung dalam penelitian Siddiqi (2011); Osman dan Sentosa (2013).

Sabir et al. (2014) menemukan bahwa terdapat hubungan positif antara kepuasan pelanggan dan loyalitas pelanggan. Salah satu alasan pelanggan berpindah brand adalah ketidakpuasan. Mereka merasakan alternatif hanya membuat lebih buruk tidak seperti brand yang mereka gunakan. Hal ini didukung oleh penelitian Siddiqi (2011) dan Osman dan Sentosa (2013) yang menemukan bahwa terdapat korelasi positif antara kepuasan pelanggan dan loyalitas pelanggan sehingga manajer harus memberikan perhatian lebih untuk meningkatkan kepuasan pelanggan. Sejumlah penelitian pada sektor pelayanan secara empiris juga telah menghubungkan antara kepuasan dan perilaku-perilaku seperti tetap menggunakan penyedia layanan yang sama dan bersedia melakukan rekomendasi word-of-mouthkarena kepuasan pelanggan membawa pelanggan menjadi loyal.

Kualitas pelayanan membawa pelanggan pada kepuasan pelanggan dan kepuasan pelanggan menyebabkan loyalitas nasabah. Dalam kompetisi bank dunia, pelayanan superior akan membawa mereka pada keuntungan.

Tabel 1. Data Pendapatan Bank Index Kantor Cabang Lampung

\begin{tabular}{ccc}
\hline Tahun & $\begin{array}{c}\text { Pendapatan(Dalam } \\
\text { Ribuan Rupiah) }\end{array}$ & Perubahan \\
\hline 2013 & 23.171 .942 & \\
2014 & 16.690 .729 & $-28 \%$ \\
2015 & 16.488 .292 & $-1,20 \%$ \\
\hline
\end{tabular}

Sumber : Annual Report Bank Index 2013-2016

Dalam jangka panjang, loyalitas pelanggan menjadi tujuan bagi perencanaan pasar strategic (Kotler dan Keller, 2008:193).Semakin banyaknya bank di Bandar Lampung dengan keunggulan produk masing-masing membuat Bank Index harus meningkatkan pelayanan dikarenakan adanya penurunan pendapatan sesuai pada Tabel 1. Hal ini diduga bahwa mulai berkurangnya kepuasan nasabah yang diakibatkan kualitas pelayanan yang diberikan oleh Bank Index KC Lampung.

Ketidakpuasan nasabah ini akan berpengaruh kepada loyalitas nasabah. Kondisi ini sangat relevan dengan temuan riset terdahulu Siddqi (2011) dan Sabir (2014) yang menyatakan bahwa kualitas layanan nasabah berdampak kepada kepuasan nasa- bah, dan kepuasan nasabah akan berpengaruh kepada loyalitas nasabah.Berdasarkan latar belakang yang telah dijelaskan peneliti ingin mengobservasi apakah kualitas pelayanan berpengaruh terhadap kepuasan pelanggan, kepuasan pelanggan berpengaruh terhadap loyalitas pelanggan, dan kualitas pelayanan berpengaruh terhadap loyalitas pelanggan pada Bank Index Kantor Cabang Lampung.

\section{TINJAUAN LITERATUR}

\section{Kualitas Pelayanan}

Cronin et al. (1988) mendefinisikan kualitas pelayanan adalah perbandingan antara pelayanan yang diharapkan pelanggan dengan pelayanan yang diterimanya. Dimensi Kualitas Pelayanan (SERVQUAL) oleh Cronin et al. (1988) dibagi menjadi lima dimensi SERVQUAL diantaranya adalah (Kotler dan Keller, 2007:56):

1. Tangibles (Bukti fisik) yaitu kemampuan suatu perusahaan dalam menunjukkaneksistensinya kepada pihak eksternal yang meliputi fasilitas fisik (gedung, gudang, dan lain sebagainya), perlengkapan dan peralatan yang dipergunakan (teknologi), serta penampilan pegawainya.

2. Reliability (Kehandalan) yaitu kehandalan merupakan kemampuan perusahaan untuk memberikan pelayanan sesuai yang dijanjikan secara akurat dan terpercaya.

3. Responsiveness (Ketanggapan) yaitu kemauan untuk membantu dan memberikan pelayanan yang cepat (responsif) dan tepat kepada pelanggan, dengan penyampaian informasi yang jelas.

4. Assurance (jaminan dan kepastian) yaitu pengetahuan, kesopansantunan, dan kemampuan para pegawai perusahaan untuk menumbuhkan rasa percaya para pelanggan kepada perusahaan.

5. Emphaty (empati) yaitu empati yaitu memberikan perhatian yang tulus dan bersifat individual atau pribadi yang diberikan kepada para pelanggan dengan berupaya memahami keinginan pelanggan. Dimana suatu perusahaan diharapkan memiliki pengertian dan pengetahuan tentang pelanggan, memahami kebutuhan pelanggan secara spesifik, serta memiliki waktu untuk pengoperasian yang nyaman bagi pelanggan.

\section{Kepuasan Pelanggan}

Customer satisfaction adalah perasaan senang atau kecewa yang dirasakan seseorang yang berasal dari perbandingan antara kesannya terhadap kinerja (hasil) suatu produk dan harapan-harapannya, dengan kata lain kepuasan sebagai evaluasi setelahmengkonsumsi suatu alternatif yang dipilih setidaknya memenuhi atau melebihi harapan (Kotler dan Keller, 2008:177). 
Berdasarkan literatur dan definisi kepuasan di atas, Siddiqi (2011) mengidentifikasi komponen kepuasan berikut:

1. Kepuasan pelanggan adalah salah satu jenis respon (kognitif atau emosional).

2. Respons tersebut menekankan pada fokus tertentu (produk, pengalaman konsumsi, harapan dll.)

3. Respon terjadi pada waktu tertentu (setelah pilihan, berdasarkan akumulasi pengalaman).

\section{Loyalitas Pelanggan}

Pearson (1996) dalam Akbar dan Parves (2009) mendefinisikan pelanggan loyal sebagai himpunan pelanggan yang memiliki sikap mendukung terhadap perusahaan, berkomitmen untuk membeli kembali produk atau jasa perusahaan, dan merekomendasikan produk atau jasa perusahaan kepada orang lain.

Ada dua dimensi untuk loyalitas pelanggan: perilaku dan sikap (Kandampully dan Suhartanto, 2014):

1. Dimensi perilaku merujuk pada perilaku pelanggan pada pembelian berulang, menunjukkan preferensi untuk suatu merek atau layanan dari waktu ke waktu.

2. Dimensi sikap, di sisi lain, merujuk pada niat pelanggan untuk membeli kembali dan merekomendasikan, yang merupakan indikator yang baik dari pelanggan yang loyal. Selain itu, pelanggan yang memiliki niat untuk membeli kembali dan merekomendasikan sangat mungkin untuk tetap bersama perusahaan.

\section{KERANGKA KONSEPTUAL}



Gambar 1.Model Analisis Penelitian

Hipotesa:

$\mathrm{H}_{1}$ : Adanya hubungan positif antara kualitas pelayanan dan kepuasan nasabah

$\mathrm{H}_{2}$ : Adanya hubungan positif antara kepuasan nasabah dan loyalitas nasabah

$\mathrm{H}_{3}$ : Adanya hubungan positif antara kualitas pelayanan dan loyalitas nasabah

\section{METODE PENELITIAN}

\section{Populasi}

Populasi dalam penelitian ini adalah jumlah nasabah pada produk Tabungan bank Index Kantor Cabang Lampung.

\section{Sampel}

Teknik sampling yang digunakan yaitu purposive sampling dengan kriteria: tabungan digunakan untuk pembayaran angsuran kredit; tabungan bisa digunakan untuk bertransaksi usaha; pengguna Tabungan Index dapat menikmati fasilitas smsmonitor, fasilitas autodebet pembayaran kartu halo, telkom, dan PLN;tabungan digunakan untuk system payroll.

Teknik penarikan sampel yang digunakan berdasarkan Rule of Thumbs mengikuti Hair et al. (2010) yaitu jumlah sampel yang ditentukan yaitu sebanyak 150 responden.

\section{Definisi Operasional Variabel}

\section{Service Quality}

a. Tangibility: diukur dari aspek fisik, teknologi yang digunakan bank, kerapihan pakaian karyawan, produk bank, dan laporan bank.

b. Reliability: diukur melalui layanan yang dijanjikan, penanganan penyelesaian masalah, layanan tepat waktu, jam operasional, laporan bank yang uptodate.

c. Responsiveness: diukur melalui kecepatan pelayanan, kesediaan dalam membantu nasabah, laporan bank yang tepat waktu.

d. Assurance: diukur melalui keamanan nasabah dalam bertransaksi, keinginan untuk bertransaksi, dan pengetahuan karyawan tentang produk.

e. Empathy: dikur melalui perhatian, kebutuhan, daya tarik, informasi

\section{Customer Satisfaction}

Menurut Siddiqi (2011) mengidentifikasi komponen kepuasan pelanggan dapat diukur berdasarkan Kepuasan konsumen diukur dari kesopanan, kepercayaan, kejelasan informasi, keamanan transaksi, layanan tepat waktu, fasilitas yang modern, layanan pertama kali yang baik, kualitas service excellent, biaya yang wajar, ATM online, nilai untuk uang.

\section{Customer Loyalty}

Dua dimensi untuk loyalitas pelanggan: perilaku dan sikap (Kandampully dan Suhartanto, 2014) dapat diukur dari hal positif yang dirasakan konsumen, 
pemasaran word of mouth, nilai untuk berbisnis, bank menjadi pilihan utama nasabah dalam bertransaksi keuangan.

\section{ANALISIS DAN PEMBAHASAN}

\section{Path Analysis}

Uji hipotesis menggunakan diagram jalur (path diagram) dan metode analisis SEM (Structural Equation Model) dengan menggunakan alat analisis yaitu AMOS Versi 20.0. Pengujian dilakukan dengan menguji signifikansi estimasi parameter model struktural Regression Weight pada SEM. Pada program aplikasi AMOS, estimasi loading struktural ini dinyatakan sebagai nilai estimasi Regression Weight (Standardized) dengan factor loading $>0.50$. Sedangkan untuk uji signifikansi menggunakan nilai $R e$ gression Weight (Unstandardized) yang akan difokuskan pada nilai critical ratio (C.R) beserta p-valuenya dari loading struktural tersebut. Jika p-value yang dihasilkan lebih kecil dari taraf signifikan (biasanya $5 \%$ atau $1 \%$ ), maka dapat diartikan bahwa konstruk independen mempunyai pengaruh yang signifikan terhadap konstruk endogenus. Pengujian hipotesis juga dapat dilakukan dengan menggunakan nilai critical ratio (C.R). Jika C.R > 1,96 (untuk $\mathrm{p}=5 \%$ ), atau C.R > 2,58 (untuk $\mathrm{p}=1 \%$ ), maka hipotesis dapat diterima menurut Dachlan (2014:356). Pada penelitian ini $p$-value yang digunakan adalah 5\% dengan nilai critical ratio (C.R) 1,96.

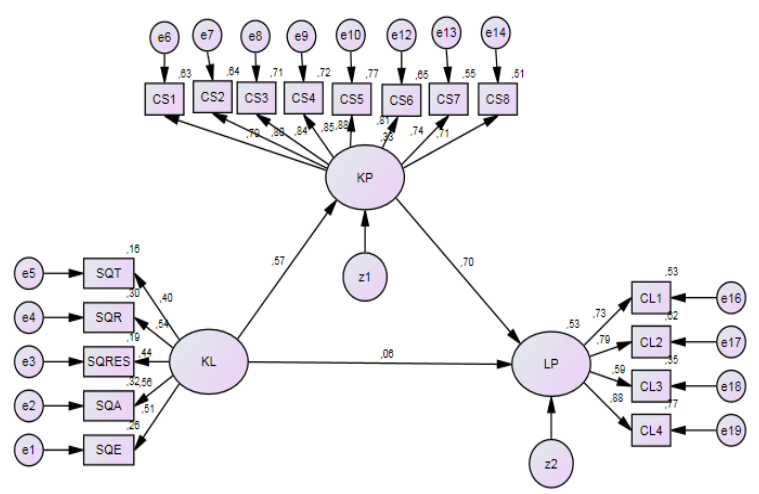

Gambar 1. Analisis Jalur SEM

Dari output AMOS yang terlihat diketahui nilai estimasi atau nilai loading factor sebesar 0,574 . Hal ini menunjukkan angka factor loading yang tinggi karena di atas 0,5. Dengan demikian, hipotesis pertama terbukti secara meyakinkan bahwa kualitas pelayanan memiliki pengaruh yang cukup kuat terhadap kepuasan pelanggan pada nasabah Bank Index yakni 57,4\%. Dari output AMOS yang terlihat diketahui nilai estimasi sebesar 0.060 menunjukkan hubungan yang lemah antara kualitas pelayanan terhadap variabel loyalitas nasabah karena kurang dari 0,5 . Oleh karena itu, hipotesis ini ditolak karena hanya memiliki pengaruh secara langsung sebesar 6\%.Hasil ini menunjukkan bahwa kualitas pelayanan tidak memiliki pengaruh yang signifikan terhadap loyalitas pelanggan pada Bank Index Kantor Cabang Lampung. Terlihat pada gambar 1 menunjukkan bahwa nilai factor loading variabel kepuasan pelanggan menunjukkan angka yang cukup tinggi terhadap loyalitas pelanggan yaitu sebesar 0,70 dan dapat disimpulkan bahwa hipotesis ini diterima. Hasil ini menunjukkan bahwa variabel kepuasan pelanggan memiliki pengaruh signifikan dan cukup kuat terhadap loyalitas pelanggan pada nasabah Bank Index yakni $69,5 \%$.

\section{HASIL DAN PEMBAHASAN}

\section{Pembahasan}

\section{Pengaruh Kualitas Pelayanan Terhadap Kepuasan Nasabah}

Semakin tinggi kualitas pelayanan Bank Index, maka akan semakin tinggikepuasan yang diterima oleh pelanggan.Berdasarkan hasil penelitian kualitas pelayanan, strategi yang telah dilakukan oleh Bank Index dalam menciptakan kepuasan pelanggan yang mendapat jawaban setuju terbanyak adalah responsiveness terutama motivasi karyawan dalam membantu nasabah. Hal ini dilakukan karyawan melalui penerapan standard service excellence dari bank dengan cara menyambut nasabah dengan membuka pintu dan menanyakan kebutuhan yang diperlukan nasabah yang dilakukan oleh security. Dalam penanganan pengaduan nasabah, bank memiliki tenggat batas waktu dalam menyelesaikan pengaduan nasabah yaitu maksimal 3 hari masa kerja.

\section{Pengaruh Kualitas Pelayanan Terhadap Loyalitas Nasabah}

Berdasarkan hasil perhitungan secara statistik diketahui bahwa kualitas pelayanan tidak berpengaruh terhadap loyalitas pelanggan.

Ada beberapa hal yang membuat variabel kualitas pelayanan tidak berpengaruh terhadap loyalitas pelanggan berdasarkan pengamatan di lapangan. Segmen responden sebagian besar merupakan pegawai swasta yang berpenghasilan cukup dengan kategori usia yang produktif dan menggunakan fasilitas Tabungan Index Payroll sehingga menggunakan Tabungan hanya untuk mengambil gaji.

Segmen responden terbesar kedua adalah wiraswasta dengan penghasilan cukup besar, responden dengan profesi wiraswasta yang menjadi segmen 
responden ini banyak yang memiliki fasilitas kredit sehingga rekening digunakan untuk pembayaran angsuran dan bunga setiap bulannya. Oleh karena itu, dapat dibilang bahwa nasabah menggunakan rekening hanya berdasarkan manfaat yang mereka dapatkan sehingga kurang sehingga masih kurangnya minat untuk menggunakan produk Bank Index lainnya.

\section{Pengaruh Kepuasan Pelanggan Terhadap Loyalitas Pelanggan}

Semakin tinggi kepuasan pelanggan maka semakin tinggi loyalitas pelanggan. Bank Index Kantor Cabang Lampung dalam menciptakan loyalitas pelanggan mendapat jawaban puas terbanyak adalah pernyataan karyawan bank terpercaya. Hal ini dibuktikan dari tidak pernah adanya tindakan fraud yang tercatat selama Bank Index Kantor Cabang Lampung berdiri. Data yang diberikan nasabah merupakan suatu kerahasiaan yang sah di mata hukum, karena itu karyawan Bank sangat melindungi kerahasiaan bank tersebut dengan cara tidak memberikan informasi apapun terkait rekening nasabah bank kepada siapapun. Hal ini juga dilandasi dengan 5 pilar budaya kerja Bank Index yaitu jujur, disipilin, produktif, efisien, dan belajar.

\section{SIMPULAN DAN SARAN}

Berdasarkan hasil penelitian kualitas pelayanan berpengaruh signifikan terhadap kepuasan pelanggan nasabah, kepuasan pelanggan berpengaruh signifikan terhadap loyalitas pelanggan,kualitas pelayanan tidak berpengaruh secara signifikan terhadap loyalitas pelanggannasabah Bank Index Kantor Cabang Lampung.

Berdasarkan hasil penelitian dan pembahasan, peneliti akan mengajukan beberapa saran yaitu ruang lingkup studi ini difokuskan pada nasabah Bank Index Kantor Cabang Lampung berdampak pada generalisasi studi yang terbatas. Keterbatasan ini mengisyaratkan perlunya studi-studi lanjutan.Pada variabel tangibility adanya kekurangan yang dimiliki perusahaan, yaitu dalam hal teknologi, untuk itu diharapkan ke depannya bank Index dapat mengimbangi kemajuan teknologi yang terkini seperti: internet banking, mobile banking, sms-banking, e-money serta peningkatan system layanan dan perluasan jaringan ATM.Pada variabel kualitas pelayanan responsiveness, disarankan untuk semua nasabah memiliki email agar pengiriman laporan bank atau rekening koran bisa langsung diterima kapanpun dimanapun.

\section{DAFTAR PUSTAKA}

Akbar, M. Muzahid and Parvez, Noorjahan. 2009. Impact of Service Quality, Trust and Customer satisfaction on Consumer Loyalty.ABAC Journal.29(1), pp. $24-38$.

Cronin, J. Joseph Jr. dan Taylor, Steven. 1992. Measuring Service Quality: Reex Amination and Extension, Journal of Marketing.56. pp. 55-68.

Dachlan, Usman. 2014. Panduan Lengkap Structural Equation Modeling. Edisi Pertama. Lentera Ilmu: Semarang.

Hair, Black, Babin, Anderson. 2010. Multivariate Data Analysis. Pearson Prentice Hall. Seventh Edition.

Kandampully, Jay and Dwi Suhartanto, 2000, Customer Loyalty in The Hotel Industry: the Role of Customer Satisfaction and Image, International Journal of Contemporary Hospitality Management, 12(6), pp. 346-351

Kotler, Philip dan Kevin Lane Keller. 2008.Manajemen Pemasaran.Jilid 1. Cetakan Ketiga. PT Indeks: Jakarta.

Kotler, Philip. dan Keller, Kevin Lane. 2007. Manajemen Pemasaran. Jilid 1 dan 2. PT Indeks: Jakarta.

Mosahab, Mahamad, Ramayah. 2010.Service Quality, Customer Satisfaction, and Loyalty: A Test of Mediation, International Business Research,3(04), pp. 72-80.

Osman, Zahir dan Sentosa, Ilham, 2013.Mediating Effect of Customer Satisfaction on Service Quality and Customer Loyalty Relationship in Malaysian Rural Tour. International Journal of Economics Business and Management Studies, 2(1), pp 25-37.

Sabir, Ghafoor, Akhtar, Hafeez. Dan Rehman, 2014. Factors Affecting Customer Satisfaction in Banking Sector of Pakistan. International Review of Management and Business Rese$\operatorname{arch}, 3(2)$, pp. 1014-1025.

Siddiqi, Kazi Omar, 2011, Interrelations between Service Quality Attributes, Customer Satisfaction, And Customer Loyalty in the Retail Banking Sector in Bangladesh, International Journal of Business and Management, 6(3), pp. 12-36.

Undang-Undang Negara Republik Indonesia. 1998. Undang-Undang Negara Republik Indonesia Nomor 10 Tahun 1998 Tanggal 10 November 1998. Retrieved fromhttp://id.wikisource.org. 